\title{
Breeding of frosthardy rhododendrons
}

\author{
M. UOSUKAINEN ${ }^{1)}$ and P.M.A. TIGERSTEDT ${ }^{2)}$ \\ 1) Agricultural Research Centre \\ Healthy Plant Center \\ SF-41340 Laukaa, Finland \\ 2) Department of Plant Breeding, \\ University of Helsinki \\ SF-00710 Helsinki, Finland
}

\begin{abstract}
In 1973 a Rhododendron breeding program was started at the Department of Plant Breeding, University of Helsinki. The program was based on the extremely hardy rhododendron material that had been naturally selected at Arboretum Mustila. The aim was to create new frosthardy cultivars that could tolerate minimum temperatures below $-35^{\circ} \mathrm{C}$ in mid-winter. Rhododendron brachycarpum subsp. tigerstedtii Nitz. was used as the maternal parent in the majority of crosses. Also $R$. smirnowii and $R$. catawbiense were used as sources for winter hardiness.

Totally 148 different combinations were done between species, species and hybrids and between hybrids. The total number of matings was 496 . Over 20000 seedlings were obtained and a total of 13752 plants were planted in field trials on eight different test sites between 1975-1979.

After two extremely cold winters, $1984 / 85$ and $86 / 87$, about $60 \%$ of the plants died or were severely damaged. $R$. brachycarpum subsp. tigerstedtii crosses with either $R$. smirnowii or $R$. catawbiense gave the best genetic material for better climatic adaptation. The progenies of these crosses survived without any severe damage when minimum temperature was as low as $-37^{\circ} \mathrm{C}$. Tissue culture methods were developed and used in vegetative propagation of selected ortets. By the end of 1987 six clones have been released as new cultivars for commercial propagation.
\end{abstract}

Index words: Rhododendron breedıng, $R$. brachycarpum subsp. tigerstedtii, $R$. smirnowii, $R$. catawbiense. selection for cold tolerance

\section{Introduction}

Rhododendrons belong to the Ericaceae(heath) family that consists of about 70 genera and 1900 species (LAwrence 1951). They are widely distributed on acid soils throughout temperate regions of northern and southern hemispheres and to a lesser extent in the subarctic. A number of ericaceous species cover the coniferous forest floor of northern 
Europe including Finland. However the genus Rhododendron is restricted to a single species, $R$. lapponicum $\mathrm{L}$., naturally distributed in the subarctic under open tundra-like conditions. The genus Rhododendron comprises about 900 species in the cool and temperate regions of the northern hemisphere with a concentration of species, about 700 , in the mountains of east and southeast Asia.

The genus Rhododendron was first recognised by Linnaeus in Species Plantarum in 1753. Recently there has been a total reversion of the genus into eight subgenera. Some of them are further split into sections and even subsections (Cullen and Chamberlain 1980). In fact, a revision of azalea types is currently undertaken and may result in the division of these rhododendrons into seven sections.

Rhododendrons have been used as ornamentals in the gardens of central Europe ever since plant explorations began their introduction from China and other parts of the world early in the 19th century. A number of famous plant hunting expeditions (Forrest, Rock, Kingdon-Ward and others) in the beginning of the 20th century introduced a large number of new rhododendron species into the gardens of Europe, particularly from China and other parts of southeast Asia (KrüssMANN 1968). This also promoted plant breeding efforts to improve the ornamental value and hardiness in new hybrids. Species within sections of rhododendrons are easy to cross and new character combinations of growth habits and flower colours can be produced almost ad libitum. Intersectional crosses are however often difficult to make and resulting hybrids are often totally sterile. Sterility may depend on strictly morphological malformations, but also ploidy levels may vary from diploid to decaploid in different species thus causing hybrids to have genomic imbalance. For instance crosses between diploids and tetraploids give sterile triploid hybrids. Ploidy level manipulations by colchicine treatments give promising results to produce new fertile alloploid rhododendrons. Thus more than a hundred years of selection and hybridisation has produced over 4800 named "cultivars" (SAlley and Greer 1986) and many more man made products have been left unregistered. Most of this plant breeding work has been done in the United Kingdom, United States and in various countries of central Europe. Thus the released cultivars are generally not hardy in northern Europe.

At present some 50000 rhododendron plants are yearly imported to Finland (ANON. 1986). The imported plants are mainly winter green Rhododendron catawbiense Michaux and deciduous $R$. japonicum (A. Gray) Suring. The first mentioned is the most commonly cultivated rhododendron species in Finland. Only some plants, grown in southern and central Finland, have shown to be of adequate hardiness (Kallio 1966). This presumably depends on genetic variation in hardiness between different individuals of the true species in combination with particularly favourable local growing conditions. The average winter minimum temperature that $R$. catawbiense can stand is $-32^{\circ} \mathrm{C}$ (Cox 1979). The minimum temperatures in southern and central Finland have been varying between $-30,6^{\circ} \mathrm{C}$ at Hanko to $-38,5^{\circ} \mathrm{C}$ at Jyväskylä (ILMATIETEEN LAITOS 1986). Also following cultivars are imported and grown regularly: 'Caractacus', 'Cunningham's White', 'Dr. H.C. Dresselhuys', 'F.D. Godman', 'Nova Zembla' and 'Scarlet Wonder'. The frost tolerance of their buds varies between $-23^{\circ} \mathrm{C}$ and $-32^{\circ} \mathrm{C}$ (Salley and Greer 1986).

It can be concluded that imported species and cultivars are generally not adequately adapted to the Finnish climate. Plants suffer particularly from cold spells below $-30^{\circ} \mathrm{C}$ that damage flower buds or sometimes vegetative buds or whole shoots. The incentive to launch a major rhododendron breeding program in Finland is based on three major facts. Firstly, it has been well proven, that imported material is not adequately adapted to the climate. Secondly, it has been shown in arboretum and garden trials that there are species of rhododendron that can stand even the coldest of winters in Finland. Thirdly, erica- 
ceous species are generally well suited to grow on the acidic forest soils and particularly on the organic peat soils in Finland.

The breeding program was started in 1973 . It was based on the extremely hardy rhododendron material that during 40 years had been grown and naturally selected at Arboretum Mustila, south east Finland, $60 \mathrm{deg}$. $44 \mathrm{~min}$. N. lat. and $26 \mathrm{deg}$. $29 \mathrm{~min}$. E. long (Tigerstedt 1986). This collection was established by Dr. C.G. Tigerstedt who had a clear notion of the importance of seed origins and variability in hardiness between plants of a population. Thus introductions were, whenever possible, made in the form of a number of individuals representing the species. In the years 1930-1950 Mr. B. Schalin, city gardner in Helsinki, established a number of rhododendron plantations in the Helsinki city parks and on his private property near Helsinki (Schalın 1953). At the Brödtorp plant nurseries, Mr. B. Knape started nursery production of rhododendrons and azaleas in 1953 (Knape 1984). Thus in 1966 Kallio reported that 40 different species and cultivars had been grown in Finland. These plantations have shown that there are a number of rhododendron species that adapt fairly well to the climate in the south-central part of the country.

The aim of the program was to produce superior species hybrids and particularly to find desirable recombinants in populations of crosses between species and hybrids. Frosthardiness has invariably been the number one trait selected for, but in addition a lot of effort has been put on selection for different growth habits of the bush, including foliar characteristics. A whole spectrum of flower colours from pure white to deep red has also been a collective target including the details of flower morphology and inner colour and feature of the corolla.

Long term testing at Arboretum Mustila has shown that $R$. brachycarpum subsp. tigerstedtii Nitz. is an exceptionally hardy species (Fig. 1). This species was named after Dr. C.G. Tigerstedt, who introduced it to the world in
1935. That year he received a seed source originating from the Kongo-San mountains in eastern-central Korea. Plants withstood $-43,5^{\circ} \mathrm{C}$ at the arboretum in February 1940 (Tigerstedt 1986). This species was the only tall, evergreen species that survived without any visible damage and flowered normally after the extreme cold winters 1984/85 and 1986/87 (Uosukainen 1988). At Anjalankoski, the official weather station of the Finnish Meteorological Institute, about $20 \mathrm{~km}$ from the arboretum, $-39.3^{\circ} \mathrm{C}$ was recorded close to the ground in January 1985 and $-39,8^{\circ} \mathrm{C}$ at the same spot in January 1987 (Ilmatieteen laitos 1985a, 1987). According to Cox (1979) it is probably the hardiest rhododendron in the world.

The exceptionally good adaptation of the "Tigerstedt" rhododendron is well documented in its ability to produce natural regeneration at Arboretum Mustila. Some of the natural seedlings have grown to large flowering shrubs. In fact, $R$. brachycarpum has been the only introduced rhododendron species able to reproduce generatively. At Arboretum Mustila there are several observations made on coniferous trees, indicating that the ultimate proof of good adaptation can be concluded from how well the generative cycle, including meiotic division and formation of pollen, functions in the new environment. The ability to regenerate naturally also indicates that the introduced species has found an ecological niche in its new environment.

Some other species of rhododendron are worth special mentioning for being hardy at Arboretum Mustila. The true form of $R$. brachycarpum, R. metternichii, and R. smirnowii are completely hardy under normal winter conditions. However, severe damage is caused by temperature around $-35^{\circ} \mathrm{C}$. According to Cox (1979) they should stand about $-26^{\circ} \mathrm{C}$. Also so called Seidel-hybrids have been hardy at Mustila. Rudolf Seidel used $R$. smirnowii, R. catawbiense and $R$. arboreum in his hybrids produced in Germany at the beginning of this century (KRÜSSMANN 1968). Particularly $R$. arboreum contributed 


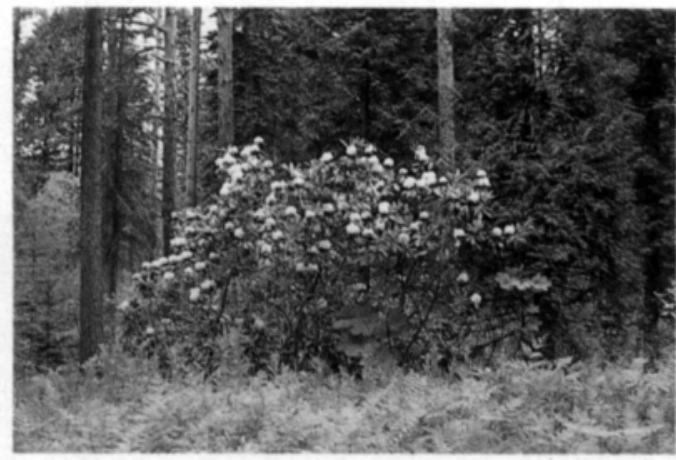

Fig. 1. Rhododendron brachycarpum subsp. tigersted$t i i$ is a tall white flowered bush. It has been used as the maternal parent in the majority of crosses in the breeding program.

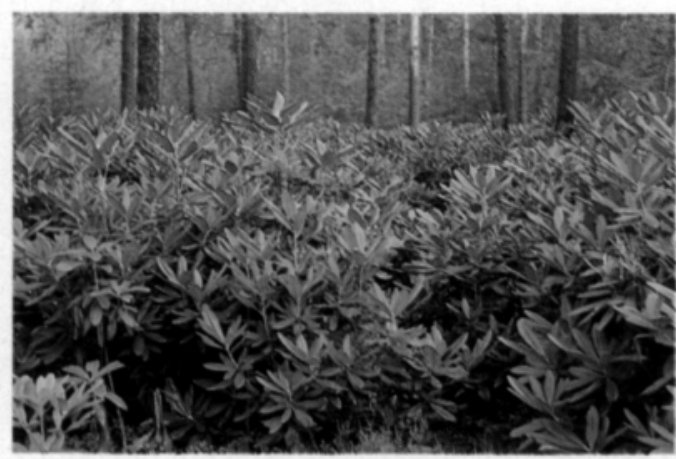

Fig. 3. The crosses between $R$. b. subsp. tigerstedtii and $R$. smirnowii resulted in very winter hardy offsprings. The F1-hybrids were medium tall bushes with a fine growth habit, attractive foliage and pinkish white flowers.

deep red flower colours to his hybrids but it was also a source of frost sensitivity.

These species and hybrids are not generally available in commercial plant nurseries because of their unsatisfactory ornamental properties or difficulties in their vegetative propagation. Their flower colours vary from pink to almost pure white and the inflorescence is often small or loose. Also their often tall and loose growth habit causes problems already during the nursery cultivation. In addition the plants are often slow flowering, requiring several vegetative years before flowering commences.

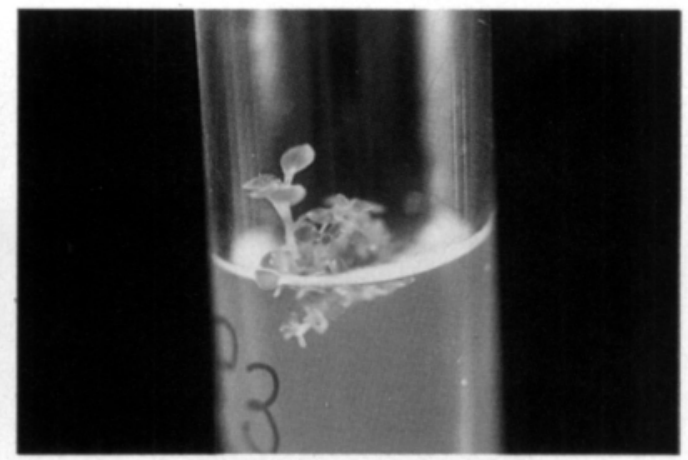

Fig. 2. Meristem tip culture methods were developed and used for clonal propagation of the selezted ortets.

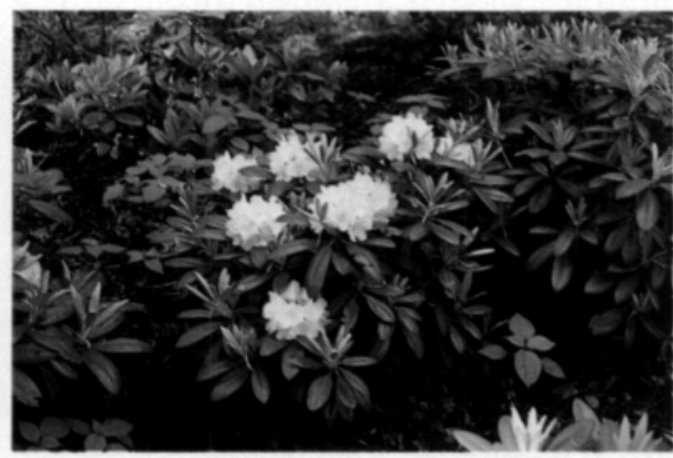

Fig. 4. F1-hybrids from the cross between $R$. b. subsp. tigerstedtii and $R$. yakushimanum are dense, low bushes. They have pubescent leaves and young shoots and white or pinkish flowers.

The comparison of climatic constraints in various places where rhododendrons are grown show that in Finland, in northern Scandinavia and in East Baltic, rhododendrons meet the marginal limits of their survival (Cox 1979, Galle 1985). In south-central Finland weather conditions are extremely variable from year to year due to fluctuations between a maritime and continental climatic profile. Night frosts in early June and again in mid August, heat and drought spells in the summer and cold spells in the winter demand a very high adaptive tolerance of successful plants. This is particularly the case when 


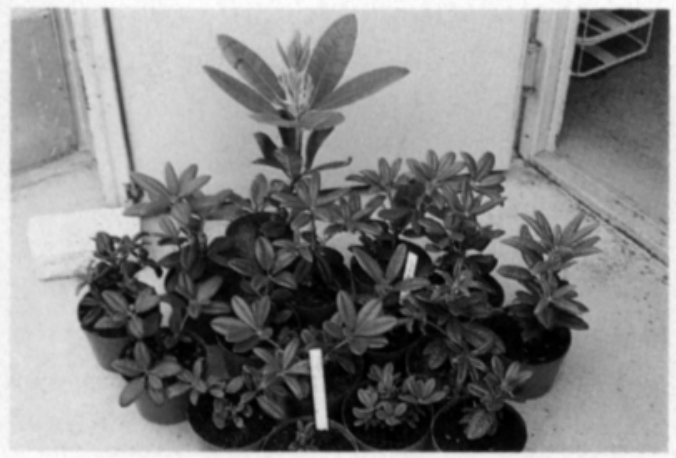

Fig. 5. The matings between a species and a hybrid, such as between $R$. b. subsp. tigerstedtii and $R$. forrestii var. repens-hybrid, gave very variable offsprings.

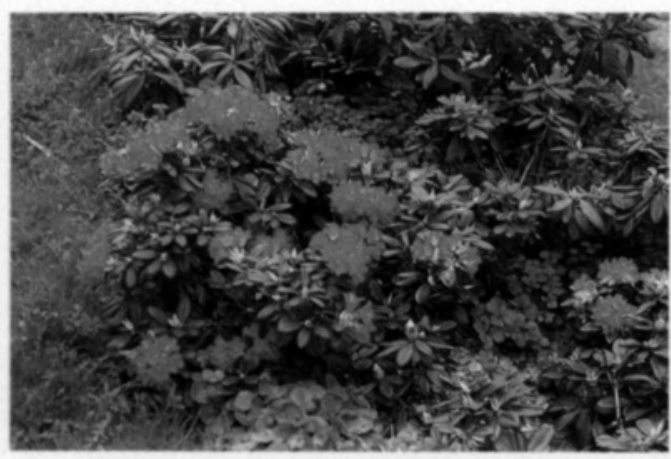

Fig. 7. The first named cultivar 'Elviira' originates from the cross $R$. b. subsp. tigerstedtii $\times R$. forrestii var. repens-hybrid. It is a low, dense bush with red buds and flowers.

growing conifers or evergreen rhododendrons. They may suffer heavily from desiccation in March-April when the solar radiation is already strong, evaporation from leaf surfaces is considerable, but water uptake is virtually nil due to frozen ground.

The taxonomic and systematic classification used in this presentation needs special commenting. Latin names and names of the cultivars have been taken from treatises by Stevenson 1930, Nitzelius 1970, Cox 1979, EnCKe et al. 1980 Salley and Greer 1986 and Krússmann 1968. There has been a great confusion in the classification of the Japanese

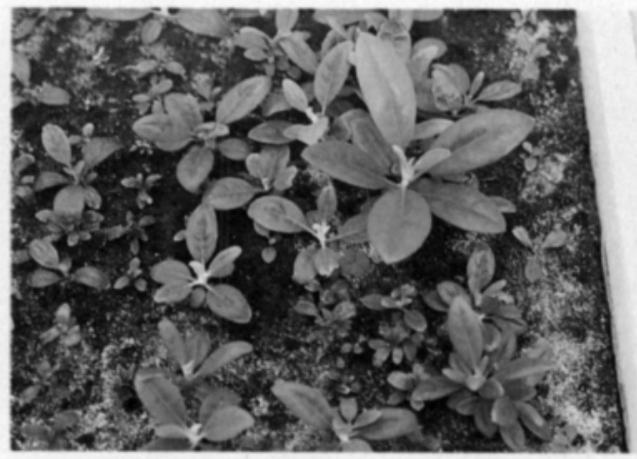

Fig. 6. Open pollinated seed was a very good source for variation and selection. The mortality among young plants and the number of weak individuals were very high particularly in the offsprings of so called Seidel-hybrids.

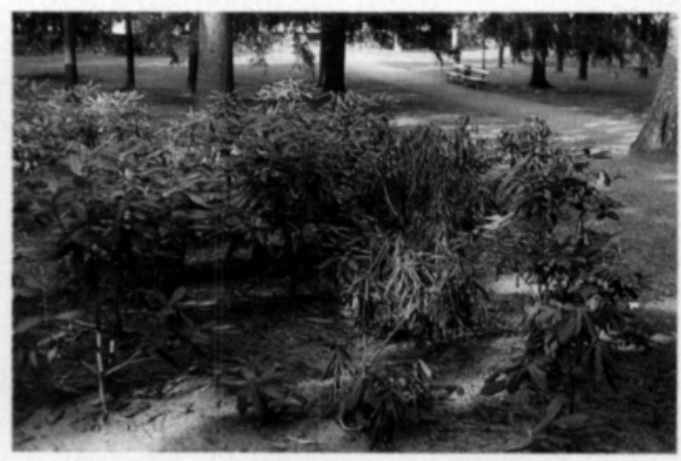

Fig. 8. In the extremely cold winters, 1984/85 and $1986 / 87$, differences in winterhardiness between hybrid progenies became clearly visible. In the picture taken from the field trial at Mikkeli, the frostbitten line in the middle resulted from the cross $R$. b. subsp. tigerstedtii $\times R$. arboreum.

Rhododendron species in Subsection Pontica. The confusion concerns $R$. degronianum, $R$. metternichii and R. yakushimanum. According to recent papers, these species are all either subspecies or varieties of $R$. degronianum (Chamberlain and Doleshy 1987). Generally the older classification has been used in this paper, because of the difficulties in determining the correct names of the used parental individuals. Thus the paternal individuals used in the crosses carry the names that were in use in the rhododendron plantations from where the pollen was collected. 


\section{Parental breeding material}

All crosses were made on mother plants selected among the hardiest species, hybrids and cultivars at Arboretum Mustila. Totally 53 mothers, belonging to 8 species and 27 hybrids were used.

The hardiest species and hybrids at Arboretum Mustila were initially used as pollinators. Also less hardy species at Mustila, but with more colourful flowering and more decorative foliage and growth habit were used as pollinators. Pollen was also procured from Bengt Schalin's garden. In 1975 new pollen sources was brought in from three rhododendron collections in south Sweden (Alnarp, Christinelund and Sofiero) and from the Royal Botanical Garden of Copenhagen in Denmark. In 1976 pollen was procured from the rhododendron collections of the Proefstation voor de Boomkwekerij at Boskoop in Holland. Totally 114 individuals belonging to 23 species and 48 hybrids were used as fathers in the crosses.

It is generally very easy to handle rhododendron pollen due to the fact that it can be preserved viable even at room temperature from several months up to a whole year. Thus species flowering at very different times can readily be hybridised. The total list of parentals used in the crosses is given in appendix 1 .

\section{Methods}

\section{Time table}

The duration of different stages of the breeding program are illustrated in Table 1 . The program was started in 1972 with preliminary crosses. On the bases of this orientation the first large scale hybridisation effort was made in 1973. The whole crossing plan was completed within six years. Progenies were raised from 1974 to 1980 simultaneously developing an optimal nursery technique. Subsequent field trials were established 19751980. First selections in the trials were made in 1978 and this work phase is planned to be completed by 1989. A research program for optimizing micropropagation of rhododendrons was carried out in 1980-1984 and subsequently applied to cloning of selected hybrids. Thus the cloning of selected ortets was started in 1982 and this work phase is estimated to take nine years. The planting of clonal field trials was started in 1983 and the work is planned to be finished by 1990 . The first cultivar was named in 1986 and the clonal selection for new cultivars is estimated to last from 1985 to 1995 . Thus the breeding program proper is estimated to take about 24 years.

\section{Pollination}

Most of the hybrids were produced by controlled hand pollination. Flower buds were emasculated just before opening and isolated in terylene bags, specially designed for tree breeding work (Duraweld Ltd., U.K.). Pollination was done after $7-14$ days when the stigma had opened and when a drop of sticky nectar revealed its readiness to accept pollen. In some cases seed after open pollination was collected as it was found that at the arboretum, pollination between species flowering simultaneously often takes place. Totally 496 cross batches were obtained in the breeding program (Appendix 2).

\section{Hybrid progenies}

Seeds were sown and progenies were raised using methods described by UOSUKAINEN (1976). The hybrid populations were planted at seven locations in southern and central Finland (Appendix 3). No plantations were done north of $65 \mathrm{deg}$. N. lat., which was considered to be the northern limit of garden rhododendrons. In the west - east direction, the climate becomes gradually more continental as the influence of the western Golf-stream gradually decreases and the influence of the vast land masses to the east of Finland increases. These facts were taken into account in selection of experimental sites for the winter 
Table 1. Timetable of the breeding program from the first crosses to the release of new cultivars.

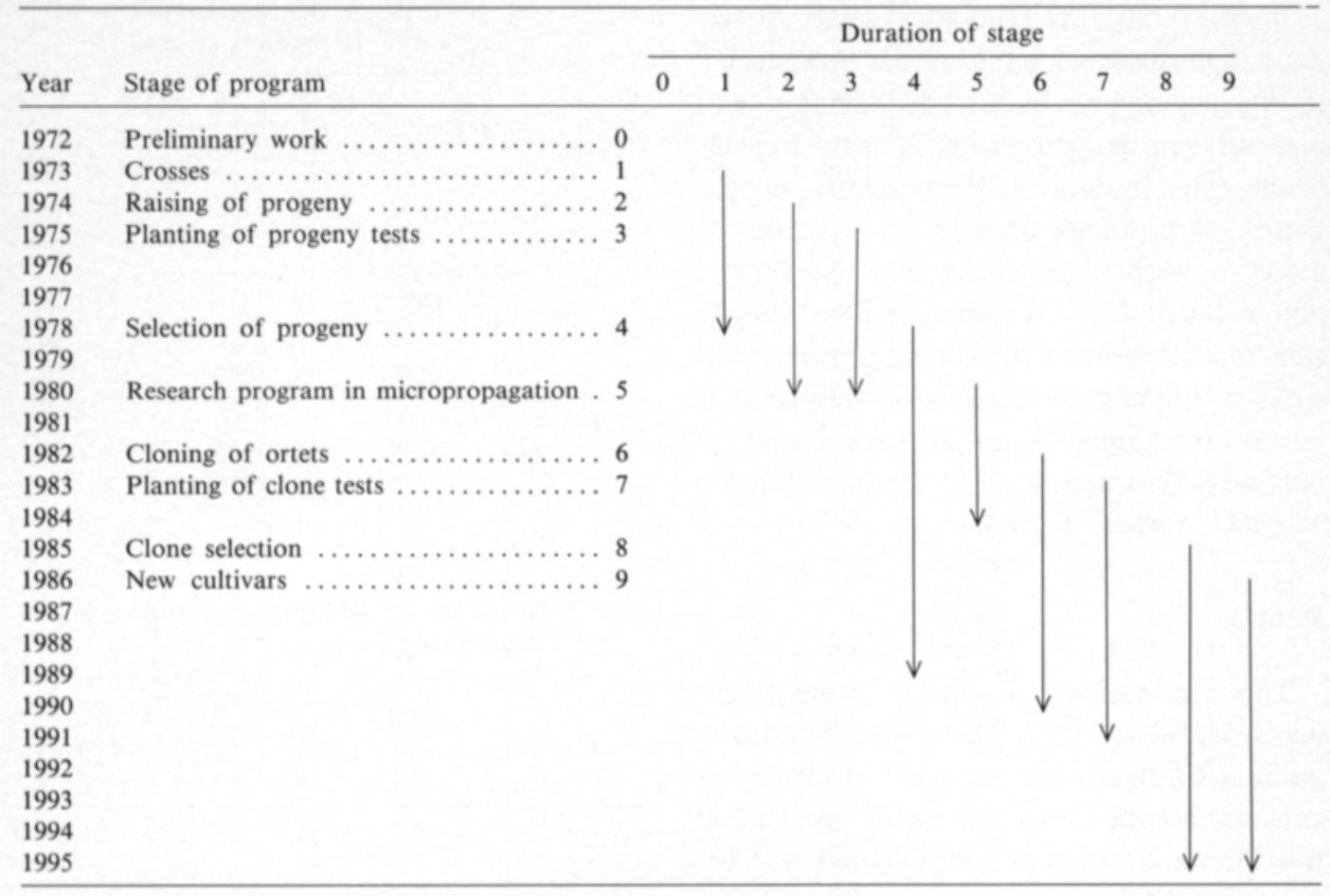

Total tenure of breeding program: 24 years.

hardiness trials. Also the hybrid populations planted were classified in hardiness groups avoiding the planting of sensitive groups in the most severe test locations.

The experimental sites also represented varying edaphic conditions. Soil types varied from glacial moraine and podsolic woodland soils to drained sphagnum swamp. All sites had a coniferous crown canopy of Scots Pine or Norway Spruce to prevent direct solar radiation.

\section{Selection criteria}

The most important selection criterion was adaptation of hybrid plants to climatic constraints. This involves several single traits, such as low temperature tolerance, growth initiation and cessation periods and drought resistance. The duration of field testing was determined to $10-15$ years depending on the occurrence of critical »bottleneck» years ( $\mathrm{T}_{1}$ -
GERSTEDT 1970). In addition following characters were considered in selection:

- Flowering characters: colours, flower and inflorescens shape, durability of flower clusters and their weather resistance, flowering period, first flowering, flowering propensity.

- Foliage characters: colour, position, shape, morphology, ageing and their resistance to nutrient disorders.

- Growth habit: creeping, shrublike, treelike, compact or loose.

- Phenology: vegetative and generative cycles.

- General plant health.

- Ageing of plants.

\section{Cloning of selected material}

In 1981 a research project was started in order to match each selected hybrid to an optimal meristem tip culture method (UosuKaI- 
NEN and NISKANEN 1985). This was necessary as it was found, that genotypes reacted differently to hormones and nutritional components in the culture medium. The selection and vegetative propagation (Fig. 2) of the hybrids is illustrated in figure 9. The vegetative propagation terminology used (ortet - ramet clone) is adopted from tree breeding (ZOBEL and TAlbert 1984). From each ortet 10-20 ramets were planted for clone testing in Helsinki, at Överby, at Kaarina, at Mäntsälä, at Arboretum Mustila, at Jyväskylä and at Haapamäki (Appendix 3.). These clonal trials were started in 1983 .

\section{Results}

The total number of matings in the breeding program was 496 . There were 442 crosspollinated batches that consisted of 148 different combinations between species, species and hybrids and between hybrids (Table 2 and Appendix 2). In addition there were 30 selfpollinated batches, 14 controls (no pollination) and 10 openpollinated seed batches. (Table 3 ). More than 20000 seedlings were obtained from the seed batches and about $25 \%$ of them died during the first year. There were also plenty of week individuals that did not survive transplanting outdoors.

Between 1975-1979 a total of 13752 plants were planted in field trials on eight different test sites. By 1982, $37 \%$ of these plants had died (Table 4) due to different reasons; unfavourable planting sites, replantings, theft and failure of care during the establishment of field trials. During the first 5-9 years after planting, poor winterhardiness was seldom the actual reason for mortality. Selection in the trials was started about three years after planting, when most plants had reached the height of $75 \mathrm{~cm}$ and thus their shoots were no longer sheltered by snow cover in mid-winter.

The frosthardiness of the breeding material was tested for the first time during the winter 1984/1985 and again two years later during in 1986/1987. These two winters were in many test sites the coldest in this century
Table 2. Number of different combinations and number of crosses (batches in parentheses), which were made in the breeding program.

\begin{tabular}{lccc}
\hline & \multicolumn{2}{c}{ Paternal } & \\
\cline { 2 - 3 } Maternal & Species & Hybrid & Total \\
\hline Species & 41 & 51 & 92 \\
& $(174)$ & $(98)$ & $(272)$ \\
& $(62$ intra specific $)$ & & \\
Hybrid & $(112$ inter specific $)$ & & \\
& 27 & 29 & 56 \\
Total & $(108)$ & $(62)$ & $(170)$ \\
& 68 & 80 & 148 \\
& $(282)$ & $(160)$ & $(442)$ \\
\hline
\end{tabular}

Table 3. Number of self pollinated, control and open pollinated seed batches.

\begin{tabular}{lrccc}
\hline & \multicolumn{3}{c}{ Type of pollination } & \\
\cline { 2 - 4 } & $\begin{array}{c}\text { Self } \\
*\end{array}$ & $\begin{array}{c}\text { Controls } \\
* *\end{array}$ & $\begin{array}{c}\text { Open } \\
* * *\end{array}$ & Total \\
\hline Species & 23 & 6 & 3 & 32 \\
Hybrids & 7 & 8 & 7 & 22 \\
\hline Total & 30 & 14 & 10 & 54 \\
\hline
\end{tabular}

* Self pollination $=$ the emasculated and isolated flowers with pollen from the same individual.

** Controls = emasculation, isolation or no isolation, no pollination.

*** Open pollination $=$ without emasculation and controlled handpollination.

Table 4. Number of planted hybrids in the field trials and the percentage of survival after establishment (1982) and after the first and second "bottleneck" winters (1985 and 1987).

\begin{tabular}{|c|c|c|c|c|}
\hline \multirow[t]{2}{*}{ Test sites } & \multirow{2}{*}{$\begin{array}{l}\text { Number } \\
\text { of planted } \\
\text { Hybrids }\end{array}$} & \multicolumn{3}{|c|}{ Survival $\%$ of plants } \\
\hline & & 1982 & 1985 & 1987 \\
\hline Mustila & 713 & 61 & 46 & 42 \\
\hline Helsinki 1 & 1600 & 68 & 31 & 26 \\
\hline Helsinki 2 & 2917 & 74 & 57 & 51 \\
\hline Vähämäki & 751 & 94 & 47 & 40 \\
\hline Piikkiō & 3129 & 69 & 59 & 54 \\
\hline Lappeenranta & 211 & 92 & 84 & 80 \\
\hline Mikkeli & 2475 & 72 & 57 & 41 \\
\hline Oulu & 1995 & 13 & 5 & 1,5 \\
\hline Total & 13752 & & & \\
\hline Mean $\%$ & & 63,5 & 46,2 & 39,3 \\
\hline
\end{tabular}

Helsinki 1 = Kaivopuisto.

Helsinki 2 = Haaga. 
(Table 5). During these winters $30 \%$ of the breeding material was either severely damaged or killed (Table 4). In winter 1986/87 particularly, there was severe root damage due to thin snow coverage during the lowest temperature period. In January 1987 the snow cover was only $10-20 \mathrm{~cm}$ in southern and central Finland (ILMATIETEen LAITOS 1987).

There were large sib-group differences between the offsprings from different mother species and cultivars. Winter survival was invariably superior in the offsprings of $R$. brachycarpum subsp. tigerstedtii. Particularly hardy were its progenies after crossing with $R$. smirnowii. These hybrids survived $100 \%$ on all test sites and over $80 \%$ had no visible damages (Fig. 3). Even the flower buds tolerated $-36^{\circ} \mathrm{C}$ without damage. Also "Tigerstedt" progenies after crosses with $R$. catawbiense and its variety album 'Glass' gave very hardy F1-hybrids. In Helsinki, all individuals of these crosses survived, $22 \%$ without damage, $56 \%$ slightly damaged and $22 \%$ with severe damages on their leaves, buds and branches. However, the reciprocal crosses indicated a strong maternal effect for hardiness inherited from the "Tigerstedt» rhododendron mother.

The matings between "Tigerstedt" and a number of other species gave somewhat less hardy offsprings than the particular ones mentioned above. Crosses with $R$. metternichii and $R$. yakushimanum gave offsprings (Fig. 4) that survived $-37^{\circ} \mathrm{C}$ but mostly with slight or even severe damages. All crosses with $R$. williamsianum, $R$. wardii or $R$. orbiculare as fathers gave offsprings with poor winter hardiness. Plants were often killed within two or three years after planting in test fields.

The matings between two hybrids or between a species and a hybrid gave extremely variable offsprings (Fig. 5). There was large variation both in morphology, flowering characteristics and in frost tolerance. Mortality was generally high in recombinant plant populations but very interesting material could be selected from such groups for further clone testing.
Table 5. The minimum temperatures at seven weather stations near the test sites (ILMATIETEEN LAITOS 1985 (a,b) and 1987).

\begin{tabular}{lccc}
\hline $\begin{array}{l}\text { Weather } \\
\text { stations }\end{array}$ & $\begin{array}{c}\text { Lowest } \\
\text { recorded } \\
\text { min.temp. } \\
{ }^{\circ} \mathrm{C}\end{array}$ & $\begin{array}{c}\text { Minimum } \\
\text { temp. } \\
{ }^{\circ} \mathrm{C} \\
1984 / 85\end{array}$ & $\begin{array}{c}\text { Minimum } \\
\text { temp. } \\
{ }^{\circ} \mathrm{C}\end{array}$ \\
\hline Mustila & $-37,3$ & $-33,2$ & $-37,3$ \\
Piikkiö & $-36,7$ & $-36,7$ & $-34,5$ \\
Helsinki 1 & $-34,3$ & $-26,5$ & $-34,3$ \\
Helsinki 2 (-52) & $-35,9$ & $-31,8$ & $-35,9$ \\
Lappeenranta & $-38,3$ & $-31,0$ & $-36,8$ \\
Mikkeli & $-42,4$ & $-34,7$ & $-36,8$ \\
Oulu (-53) & $-40,1$ & $-36,5$ & $-37,5$ \\
\hline
\end{tabular}

Mustila: Weather station of Anjalankoski.

Helsinki 1: Weather station of Kaisaniemi.

Helsinki 2: Weather station of Helsinki-Vantaa airport.

Open pollinated seed, collected at the Arboretum Mustila rhododendron valley, was a very good source for variation and selection. The mortality was very high particularly in the offsprings of $R$. smirnowii and the so called Seidel-hybrids (Fig. 6). In many cases the offsprings died already as seedlings due to fungal diseases, such as Botrytis cinerea. Some of these recombinant populations died totally in the field within the first five years. Among the surviving recombinants, beautiful flower colours and shapes were often combined with satisfactory winter hardiness.

By the end of 1987 about 80 individuals from hybrid populations had been selected to be used as ortets for micropropagation. The ramets were planted in clonal trials for further selection. By the end of 1987 a total of 2410 ramets from 35 ortets have been planted in the field for repeated clone testing. Six hybrid clones have been released as named cultivars to commercial production. There are two red flowered hybrids, 'Elviira' (Fig. 7) and 'Hellikki', two hybrids with pink flowers, 'Haaga' and 'Universitas Helsingiensis 350 ' and two white hybrids, 'St. Michel' H42 and 'P.M.A. Tigerstedt'.

\section{Discussion}

Evergreen rhododendrons are typically 
plant species that prefer maritime climates. In Europe, rhododendron breeding and use is concentrated to Ireland and the U.K., the Benelux and coastal northwest Germany. In North America the Pacific Northwest is the optimal area with some additional areas on the east coast. In Asia, Japan is the center of breeding and use although they have concentrated their efforts on the deciduous azaleas.

Extremely low winter temperatures, below $-35^{\circ} \mathrm{C}$, under conditions of little snow coverage is particularly detrimental to flower buds of rhododendrons. Critical low temperatures for flower bud damage may vary within species depending on the seed origin. Just as in conifers, a difference of one degree latitude or $100 \mathrm{~m}$ altitude may be critical for frost hardiness. Thus it is obviously somewhat uncritical to classify species of rhododendrons as hardy or not hardy in a certain location without simultaneously noting the seed origin, including the specific site from where seed was initially procured.

Particular attention must here be given to the seed origins of Rhododendron brachycarpum. There seem to be controversial opinions about the taxonomic classification of this species and some scientists have questioned the justification to separate it into subspecies (Chamberlain and Doleshy 1987). From a strictly population genetic aspect, it may well be that this species varies gradually (clinal variation) within its natural distribution in Japan and Korea. Thus the subspecies tigerstedtii may well represent the extreme end of a cline where hardiness and even morphological traits deviate considerably from the typical $R$. brachycarpum.

The fact that there is considerable genetic variation in hardiness of different seed sources of a species is worth special consideration from the plant breeder. In fact, there may even be variation in hardiness between individuals belonging to the same seed source. Thus the breeder must a priori select the basic material for hybridization from seed sources originating from climatically marginal lowtemperature areas of the species. Secondly, the breeder may considerably improve hardiness breeding by using parental material that has already been naturally selected for winter hardiness in a new critical environment. This was the case in the present rhododendron breeding program, where the parental material, particularly on the maternal side, has been naturally selected in the arboretum for periods up to 40 years. Particularly hybrid populations, where both parents had been through selection at Arboretum Mustila exhibited outstanding climatic adaptation. Much hardiness was usually lost by using imported pollen from ornamentally interesting plants that had grown in better climatic conditions in southern Scandinavia or central Europe.

Critical low temperatures also damage the vegetative bud, although its hardiness is usually greater than that of the flower bud. Ultimately low temperatures may damage or kill annual shoots thus totally destroying rhododendron plants. This often occurs only after plants have grown above the snow cover, to a height of $50-100 \mathrm{~cm}$ in south - central Finland (Fig. 8).

In addition to the direct effects of low temperature on bud or shoot damage, evergreen rhododendrons may, as mentioned above, indirectly suffer from low temperatures due to frozen ground and subsequent desiccation. This "sunburn-effect» usually occurs in late winter or early spring when the ground is still frozen, but solar radiation is already intensive, particularly due to the strong reflection from the white snow around the plants. This particular condition is typical of the Finnish climate. In fact the Finnish language has a special word (ahava) for this kind of "sunburneffect». It is particularly fatal to evergreen rhododendrons that grow on south slopes under heavy solar radiation but it may even damage indigenous evergreen conifers.

From the description above we conclude, that rhododendron field trials following hybrid breeding must continue at least until the test plants reach a height well over the snow cover. This may require a test period of at least 10 years for high-bush types, while this 

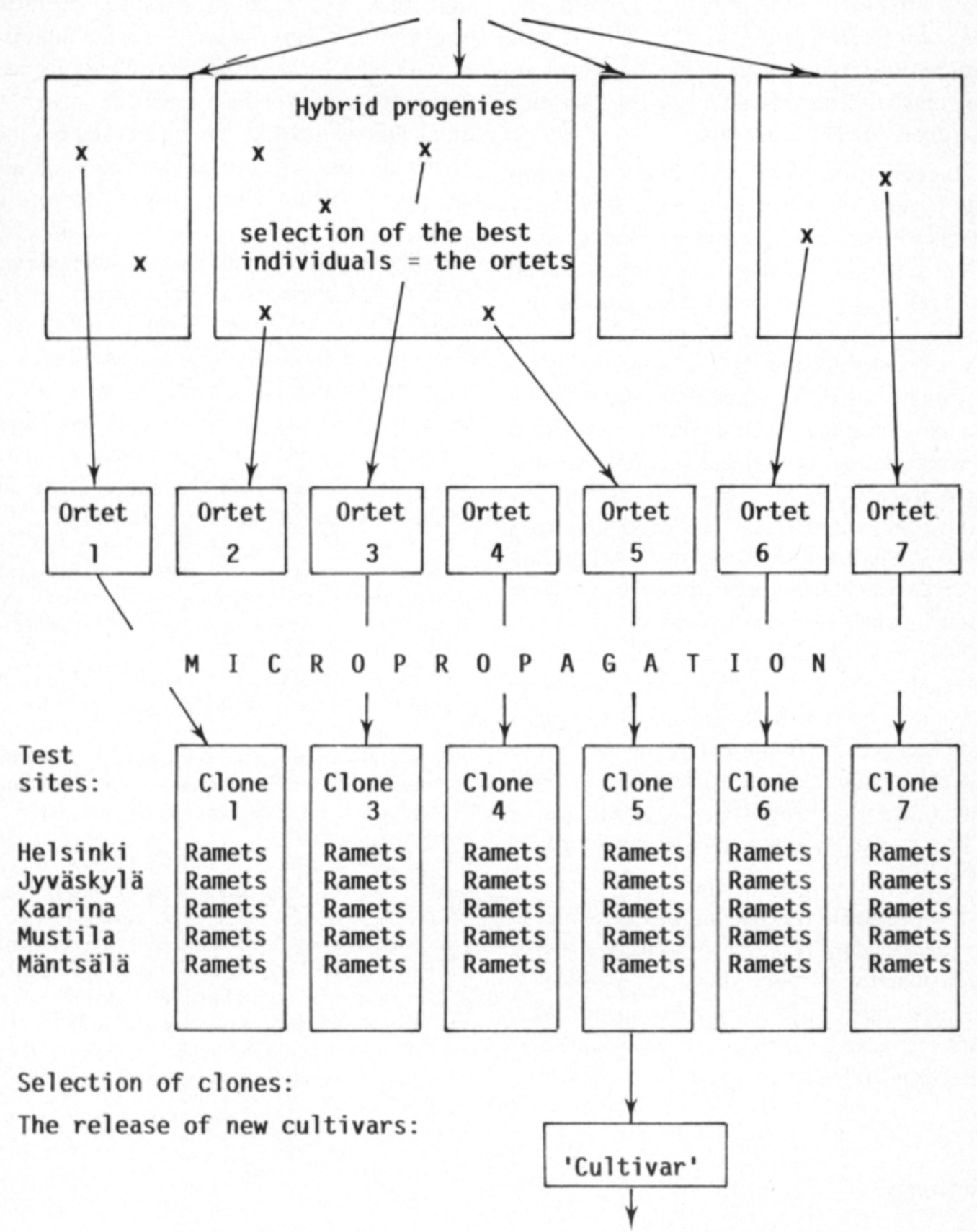

\section{Commercial production}

Fig. 9. Selection of ortets in hybrid progenies, micropropagation of ramets, planting of clone tests and the release of new cultivars.

question may be uninteresting for procumbent growth types.

However, observations at Arboretum
Mustila have indicated, that each 15-year period during this century has experienced at least one critical year for determining woody plant 
hardiness. In the rhododendron program we have been lucky to have two such years with one year interval, but generally a $10-15$ year test period is mandatory so that progeny testing may with reasonable precision determine hardiness of new cultivars.

Breeding for extreme hardiness is inevitably a very long-term enterprise. It actually starts with the geographical selection of marginal seed sources of wild species. The seed sources are then grown as plant populations in the experimental area (Arboretum) whereby natural conditions further select hardy individuals within the population. This phase of "passive breeding" should take the population through at least one critical »bottleneck» year at a stage when the plants are already far above snow coverage. The rhododendrons used in the breeding program at Arboretum Mustila were introduced in the 1930 s and have gone through $3-4$ very critical winter periods where natural selection has been ruthless. Hybrids produced in the breeding program have now been in field trials for $8-13$ years and breeder selection is still going on. Selected and cloned material has been out in replicated field trials (clone tests) for about 5 years. These tests are planned to continue until 1995 (Table 1).

Considerable time-saving can be achieved in the breeding program by effective use of meristematic cloning. Field trials of new hybrids must also be given proper time (10-15 years) to obtain reliable hardiness selection and also to select for ornamental values. However, meristematic cloning of possible cultivar candidates (ortets) can be started during the field trial period so that material is available for replicated clonal testing once the selection decision has been made. Also optimal cloning methods can be worked out individually for each cultivar candidate so that they are available when cultivar decision is made.

Deliberate breeding for climatic adaptation, such as hardiness, is a long process, often covering half a century to be on a firm genetic resource basis. In the rhododendron breeding program described here, the crosses between $R$. brachycarpum subsp. tigerstedtii and either $R$. smirnowii or $R$. catawbiense gave the best genetic material for the future efforts to breed for better climatic adaptation.

Acknowledgements. We wish particularly to express our gratitude to Mrs. Sylvi Lehtonen for her valuable assistance, professional skill, enthusiasm and personal devotion to this program.

We are grateful to Arboretum Mustila for allowing us to use the living collection of rhododendrons for the breeding program.

We wish also to express our gratitude to the Academy of Finland and to the horticultural research foundation of Nikolai and Ljudmila Borisoff for financing this research program.

We are also grateful to the City Park Department of Helsinki, the City Park Department of Mikkeli, the Department of Horticulture at the Agricultural Research Centre, the Research Farm Kotkaniemi of Kemira Oy, the University of Oulu and to Mr. Niilo Karhu. They have all given us land for the field trials of the hybrid progenies. Without their help in planting and careing of the test fields the establishment of the field trials in their present extent would not have been possible.

\section{References}

ANoN. 1986. Maatilahallituksen tuontitilastot. (Import statistics. Govt. Agric. Bureau). Helsinki.

Chamberlain, D.F. \& Doleshy, F. 1987. Japanese members of Rhododendron subsection Pontica: Distribution and classification. J. Jap. Bot. 8: 225-243.

Cox, P.A. 1979. The larger species of rhododendron. 352 p. London.

Cullen, J. \& Chamberlain, D.F. 1980. A preliminary synopsis of the genus Rhododendron. Notes R. Bot. Gard. Edinburg 36: 105-126.
Encke, F., Buchieim, G. \& Seybold, S. 1980. Zander Handwörterbuch der Pflanzennamen. 844 p. Stuttgart. Galle, F. 1985. Azaleas. 438 p. Oregon.

Ilmatieteen laitos 1985a. (Finnish Meteorological Institute). Kuukausikatsaus Suomen ilmastoon. Tammikuu 1985. 79: 1 .

- 1985b. (Finnish Meteorological Institute). Kuukausikatsaus Suomen ilmastoon. Helmikuu 1985. 79: 1.

- 1986. (Finnish Meteorological Institute). Kuukausikatsaus Suomen ilmastoon. Yhteenveto 1986. 80: 1. 
- 1987. (Finnish Meteorological Institute). Kuukausikatsaus Suomen ilmastoon. Tammikuu 1987. 81: 1.

KAlıı. T.K. 1966. Koristepuiden ja -pensaiden levinneisyydestä ja menestymisestă Suomessa. Ann. Agric. Fenn. 5, Suppl. 1. 107 p. Helsinki. (In Finnish with German summary).

KNAPE, B. 1984. Sådd- och odlingsförsök med Rhododendron i Brödtorp 1953-1983 (Sowing and cultivation experiments on rhododendrons at Brödtorp, SW Finland, in 1953-1983). Sorbifolia 15: 27-33.

KrOSSMANN, G. 1968. Rhododendren, andere immergrüne Laubgehölze und Koniferen. 190 p. Hamburg, Berlin.

- 1986. Manual of cultivated broad-leaved trees \& shrubs. Vol III, PRU-Z. 510 p. London.

LAWRence, G.H.M. 1951. Taxonomy of vascular plants. 823 p. New York.

Nitzelius, T.G. 1970. Rhododendron brachycarpum D. Don ex G. Don ssp. tigerstedtii, eine neue Unterart. Deut. Baumschule 22: 207-212.

Salley, H.E. \& Greer, H.E. 1986. Rhododendron hybrids. A guide to their origins. 391 p. London.

Schalin, B. 1953. Koristepensaista kauneimmat. 141 p. Porvoo, Helsinki.

Stevenson, J.B. 1930. The species of Rhododendron. Rhodod. Soc. 855 p. Edinburgh.

Tigerstedt, P.M.A. 1970. Dendrological Experiments at Arboretum Mustila. Lustgården 1970: 141-174. (In Swedish with English summary).

- 1986. Arboretum Mustila. Publ. Finnish Dendrol. Soc. Vol. 2. 28 p. Helsinki.

Uosukainen, M. 1976. Alppiruusun (Rhododendron sp.) siemenlisăys ja taimikasvatus. Dendrologian Seuran Tiedotuksia 7: 44-50.

— \& Niskanen, A.-M. 1985. Meristem tip culture of woody perennials. Hereditas, Suppl. Vol. 3: 153-154.

- 1988. Utvintringskador på Rhododendron och andra Ericaceae văxter vintern 1984/85. Manuscr. 6 p. (Available at Agric. Res. Centre, Laukaa, Finland).

Zobel, B.J. \& TAlbert, J.T. 1984. Applied forest tree improvement. 505 p. New York, Chichester, Bisbane, Toronto, Singapore. 


\title{
SELOSTUS
}

\section{Talvenkestävien alppiruusujen jalostus}

\author{
M. Uosukainen") ja P.M.A. Tigerstedt ${ }^{2)}$
}

1) Maatalouden tutkimuskeskus

Tervetaimiasema 41340 Laukaa

\section{2) Kasvinjalostustieteen laitos \\ Helsingin yliopisto \\ 00710 Helsinki}

Alppiruusut (Rhododendron sp.) kuuluvat Ericaceaeeli kanervakasvien heimoon ja sukuun kuuluu lähes 900 , etupäăssă aasialaista lajia. Alppiruusujen jalostus käynnistyi Keski-Euroopassa ja Pohjois-Amerikassa 1800-luvun loppupuolella. Kohta sata vuotta kestäneen jalostustyön tuloksena on yli 4800 nimettyă lajiketta rekisteröity virallisesti. Suuresta lukumäärästä huolimatta ei năiden lajikkeiden joukosta löydy Pohjois-Euroopassa hyvin menestyviä lajikkeita. Heikosta talvenkestävyydestä huolimatta tuodaan Suomeen vuosittain noin 50000 alppiruusun tainta Keski-Euroopan taimitarhoista.

Helsingin yliopiston kasvinjalostustieteen laitoksella käynnistettiin vuonna 1973 alppiruusujen (Rhododendron sp.) jalostusohjelma, joka perustui Mustilan arboretumin kestäväăn alppiruusuaineistoon. Erityisen kestävăksi alppiruusuksi osoittautui korealainen kookas, valkeakukkainen laji $R$. brachycarpum subsp. tigerstedtii Nitz. eli mustilanalppiruusu. Erinomaisen talvenkestävyytensä vuoksi tămă laji valittiin jalostusohjelman keskeiseksi lajiksi. Pyrkimyksenä oli yhdistaaă mustilanalppiruusun talvenkestävyys ja muiden sitä arempien lajien ja lajikkeiden koristeellinen kasvutapa ja kaunis kukinta. Muita keskeisiä lajeja ohjelmassa olivat $R$. catawbiense, $R$. metternichii, $R$. smirnowii ja $R$. yakushimanum.

Risteytysohjelmassa kăytettiin äiteină kaikkiaan 53 Mustilan arboretumissa kasvavaa alppiruusuyksilöă. Ne kuuluivat 8 lajiin ja 27 niistă oli hybridejä. Pölyttäjină kãytettiin kaikkiaan 114 yksiloă, joista osa oli Mustilan arboretumista tai muista suomalaisista alppiruusukokoelmista ja osa siitepölystä haettiin Ruotsista, Tanskasta ja Hollannista. Pölyttäjien joukossa oli 23 lajia ja 48 hybridiä. Käytetyt hybridit on lueteltu liitteessä 1 .

Risteytysohjelmassa tehtiin kaikkiaan 148 erilaista lajien, lajien ja hybridien ja hybridien välistä risteytystä. Niiden lisăksi tehtiin 30 itsepölytyserảă sekä 14 kontrollierăă, joissa emaskuloitua kukintoa ei pölytetty. Vapaapölytteisiă eriä oli 10. Kaikkiaan risteytysohjelmassa oli 496 risteytyseraaa. Risteytysten tuloksena saatiin yli 20000 siementainta, joista ensimmäisen elinvuoden aikana kuoli noin $25 \%$.

Jälkeläiskokeet perustettiin seitsemälle paikkakunnalle: Elimäelle, Helsinkiin, Piikkiooön, Kotkaniemen Văhä- mäkeen, Mikkeliin, Lappeenrantaan sekă Ouluun. Vuosina 1975-79 jälkeläiskokeisiin istutettiin kaikkiaan noin 14000 tainta. Vuoteen 1982 mennessä oli istutetusta aineistosta kuollut $37 \%$ eri syistä johtuen. Huono talvenkeståvyys oli ensimmäisinä vuosina vain harvoin syynă taimien menehtymiseen; useimmiten syynă oli epăsopiva istutuspaikka tai taimien väärä hoito istutusten jälkeen. Hyvin usein taimia myös varastettiin koepaikoilta.

Aineiston valinta käynnistyi, kun taimet olivat noin 75 $\mathrm{cm}$ :n korkuisia, eli niiden latvat olivat lumipeitteen yläpuolella keskitalvellakin. Tärkein valintaperuste oli ilmastollinen sopeutuminen, kuten pakkasenkestävyys, hallankestävyys ja kasvukaudenaikaisen kuivuuden kestävyys. Muita valintaperusteita olivat kukintaominaisuudet, lehdistön koristeellisuus, pensaan kasvutapa, kasvullisten ja suvullisten jaksojen rytmittyminen, kasvien terveys ja kasvien ikääntyminen.

Risteytysaineiston talvenkestävyyttä testattiin kylminä talvina 1984/85 ja 1986/87. Nämä kaksi talvea olivat useimmilla koepaikkakunnilla vuosisadan kylmimmăt. Erityisesti talvella 1986/87 esiintyi poikkeuksellisen runsaasti juuristovaurioita. Mainittujen kahden kylmän talven seurauksena noin $30 \%$ risteytysaineistosta kuoli tai vaurioitui niin pahoin, ettă ne poistettiin koekentiltä.

Risteytysjälkeläistöjen kesken oli huomattavia eroja talvenkestăvyydessä. Mustilanalppiruusun $(R$. b. subsp. tigerstedtii) jälkeläiset olivat talvenkestävyydeltảän selvăsti parhaimmat. Kun se risteytettiin nukka-alppiruusun (R. smirnowii) kanssa saatiin erityisen kestäviä jälkelăistöjä. Samoin, kun pölyttäjänä käytettiin puistoalppiruusua ( $R$. catawbiense), saatiin hyvin kestäviä, joskaan ei kovin koristeellisia jälkeläisiä. Resiprookkiset risteytykset osoittivat mustilanalppiruusun voimakkaan äidinvaikutuksen talvenkeståvyyden periytymisessä. Sen sijaan sen kookas kasvutapa ei periytynyt voimakkaasti jălkelăistöön. Risteytyksistä kääpiölajikkeiden kanssa saatiin hyvin hillittykasvuisia, usein kasvutavaltaan kompakteja hybridijälkeläisiä.

Risteytysaineistosta valittiin kaikkiaan noin 80 parasta hybridi yksiloä tarkempia lajikekokeita varten. Niiden lisảămiseksi kehitettiin meristeemilisảysmenetelmä, jonka avulla kloonattiin lajikekokeita varten tarvittavat tai- 
met. Lajikekokeita alettiin perustaa vuonna 1983 seitsemălle paikkakunnalle Etelä- ja Keski-Suomeen. Vuoden 1987 loppuun mennessä kuusi hybridi-kioonia oli laskettu kaupalliseen lisảykseen. Lajikkeet 'Elviira' ja 'Hellikki' olivat punakukkaisia, 'Haaga' ja 'Universitas Helsingiensis 350' olivat vaaleanpunakukkaisia sekä 'St. Michel' H42 ja 'P. M. A. Tigerstedt' olivat valkeakukkaisia.

Jalostusohjelman tuloksena on Suomeen saatu alppiruusulajikkeisto, jonka alhaisten lämpötilojen kestävyys on ainakin $-35^{\circ} \mathrm{C}$ ja osa lajikkeista kestaă jopa $-40^{\circ} \mathrm{C}$ :een pakkasia ilman mainittavia vaurioita. Tăten alppiruusujen viljelyaluetta voidaan Euroopassa ja Amerikassa laajentaa sekă pohjoiseen ettă ilmastoiiaan mantereisille alueille.

Monivuotisten puuvartisten koristekasvien jalostus vaatii runsaasti aikaa. Alppiruusun jalostusohjelma vie arviolta noin 20 vuotta. Talvenkestävyyden testauksessa kenttäolosuhteissa on otettava huomioon se, että Suomessa esiintyy keskimäärin 10-15 vuoden vălein ns. npullonkaulavuosi», eli normaalia kylmempi vuosi. Täten jälkeläiskokeita suunniteltaessa on niiden kesto arvioitava siten, että ainakin yksi »pullonkaulavuosi» osuu kokeen ajaksi. 
Appendix 1. Parental species, subspecies and hybrids that have been used in the breeding program. The maternals are all from Arboretum Mustila. The paternals originate from seven different Rhododendron collections. Names are according to collection labelling.

\section{Maternal plants at Arboretum Mustila:}

Names

Number

of indi-

viduals

Species and subspecies:
$R$. brachycarpum D. Don ex G. Don
$R$. brachycarpum subsp. tigerstedtii Nitz.
$R$. catawbiense Michaux
$R$. dichroanthum subsp. scyphocalyx (Balf.f. \& Forrest) Cowan
$R$. japonicum Suringar
$R$. luteum Sweet
R. schlippenbachii Maxim.
R. smirnowii Trautv.

2

Hybrids:

\begin{tabular}{lr} 
& 2 \\
& 10 \\
& 1 \\
& 1 \\
& 1 \\
& 1 \\
& 2 \\
& 8 \\
\hline Total & 26
\end{tabular}

$R$. 'Dr. H.C. Dresselhuys', (den Ouden, 1920)

R. 'English Roseum', (A. Waterer)

$R$. 'Roseum Elegans', (A. Waterer, before 1851)

$R$. Catawbiense-hybrid (dark red, n:o 42 at Mustila)

R. $\times$ fraseri W. Wats. (= R. 'Fraseri')

$R$. Oreodoxa-hybrid, (n:o 66 at Mustila)

$R$. Smirnowii Seidel-hybrids (Seedlings from 1930's)

$R$. Smirnowii-hybrid, (n:o 76 at Mustila)

$R$. Williamsianum-hybrid, (n:o 6 at Mustila)

$R$. hybrid (bright red, n:o 16 at Mustila)

$R$. hybrid (dark red, n:o 20 at Mustila)

Total 27

Number of mother plants: $\quad 53$

\section{Paternal species and hybrids:}

\begin{tabular}{ll}
\hline Names & $\begin{array}{l}\text { Number } \\
\text { of indi- } \\
\text { viduals }\end{array}$ \\
\hline
\end{tabular}

\subsection{Arboretum Mustila:}

Species:
R. adenophorum Balf. f. \& W. W. Sm.
$R$. brachycarpum D. Don ex. G. Don
$R$. brachycarpum subsp. tigerstedtii Nitz.
$R$. catawbiense Michaux
$R$. catawbiense Michaux var. album Glass
$R$. dichroanthum subsp. scyphocalyx (Balf.f. \& Forrest) Cowan
$R$. luteum Sweet
R. metternichii S. \& Z.
R. schlippenbachii Maxim.
R. smirnowii Trautv.

Hybrids:

$R$. 'Cunningham's White' (Cunningham, 1850)

$R$. 'Dr. H.C. Dresselhuys' (den Ouden, 1920)

$R$. 'English roseum' (A. 'Waterer)

$R$. 'Scarlet Wonder' (Hobbie/Le Feber 1960)

$R$. Brachycarpum-hybrid (bright red n:o 81)

$R$. Catawbiense 'Album'

$R$. Repens-hybrid (N:o 92, Mustila)

$R$. $\times$ fraserii (W. Wats.)

$R$. Orbiculare-hybrid (N:o 8, Mustila)

$R$. Oreodoxa-hybrid (N:o 66, Mustila)

$R$. Seidel's hybrid (N:o 57, Mustila)

$R$. Smirnowii Seidel-hybrids (Mustila)

$R$. Smirnowii-hybrid (N:o 76, Mustila)

$R$. Williamsianum-hybrid (N:o 6, Mustila)

$R$. hybrid (bright red, N:o 16, Mustila)

$R$. (hybrid 73-109-29) (Elimäki)

Total 27

2.2. Bengt Schalin, Jorvas, Finland 1973 and 1975 Species:

$R$. albrechtii Maxim.

R. forrestii var. repens, Reute, (Balf.f. \& Forrest) Cowan \& Davidian

R. schlippenbachii Maxim.

$R$. smirnowii Trautv.

\begin{tabular}{ll} 
& 1 \\
& 1 \\
& 1 \\
\hline Total & 4
\end{tabular}

Hybrids:

$R$. 'Elisabeth Hobbie' (Hobbie, 1945)

$R$. 'Gertrud Schäle' (Hobbie, 1951)

$R$. 'May Day' (A.M. Williams, 1932)

$R$. Calophytum-hybrid

$R$. Williamsianum-hybrid

\begin{tabular}{cc} 
& 1 \\
& 1 \\
& 1 \\
& 1 \\
& 1 \\
\hline Total & 5
\end{tabular}

2.3. The Swedish Agricultural University, Alnarp, Sweden 1975:

Species:

R. yunnanense Franch.

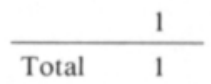

Hybrids:

$R$. 'America' (M. Koster \& Sons, 1920)

$R$. 'Bow Bells (Rothschild, 1934)

$R$. 'Dir. E. Hjelm', (D.A. Koster)

$R$. Fortunei-hybrid

\begin{tabular}{ll} 
& 1 \\
& 1 \\
& 1 \\
& 1 \\
\hline Total & 4
\end{tabular}

2.4. Christinelund, Sweden 1975 :

$R$. arboreum $\mathrm{Sm}$.

$R$. hybrid (very dark, unknown)

\begin{tabular}{ll} 
& 1 \\
& 1 \\
\hline Total & 2
\end{tabular}

2.5. Sofiero, Helsingborg, Sweden 1975:

Species:

$R$. orbiculare DC., 5224 Kew

$R$. yunnanense Franch.

\begin{tabular}{ll} 
& 1 \\
& 1 \\
\hline Total & 2
\end{tabular}


Hybrids:

$R$. 'Britannia' (C.B. van Nes, 1921)

R. 'Elisabeth Hobbie' (Hobbie, 1945)

$R$. 'Margarete Waterer'

$R$. 'May Day' (A.M. Williams, 1932)

$R$. 'Old Port' (A. Waterer, 1865)

R. 'Pink Pearl' (J. Waterer, before 1897)

$R$. Williamsianum-hybrid, Böhlje 1957

\begin{tabular}{ll} 
& 1 \\
\hline Total & 7
\end{tabular}

2.6. The Royal Botanical Garden, Copenhagen, Denmark 1975:

Species:

R. campylocarpum Hook. f.

$R$. decorum Franch.

$R$. degronianum Carr. 4341/52

$R$. degronianum Carr.

R. metternichii S. \& Z.

R. metternichii S. \& Z. hondoense

$R$. wardii W. W. Sm.
2.7. Proefstation voor de Boomkwekerij, Boskoop, Holland 1976:

Species:

$R$. decorum Franch.

1

R. forrestii var. repens (Balf.f. \& Forrest) Cowan \& Davidian

$R$. impeditum Balf. f. \& W. W. Sm.

$R$. lutescens Franch.

R. metternichii S. \& Z.

$R$. orbiculare DC.

$R$. williamsianum Rehd.

$R$. yakushimanum Nakai

R. yunnanense Franch.

\begin{tabular}{cc} 
& 1 \\
& 1 \\
& 1 \\
& 2 \\
& 1 \\
& 1 \\
& 2 \\
& 2 \\
\hline Total & 12
\end{tabular}

Hybrids:

$R$. 'Dr. Ross' (Boskoop)

$R$. 'Thunderstorm'

$R$. 'Vulcan' (Waterer, Sons \& Crisp, 1938) 1

$R$. orbiculare $\times \mathbf{R}$. dichroanthum (Boskoop)

$R$. Thuinhybrid scyphocalyx (Boskoop)

$R$. Wardii-hybrid astrocalyx (Boskoop)

\begin{tabular}{ll} 
& 2 \\
\hline Total & 8
\end{tabular}

\begin{tabular}{rrr} 
& Total & 6 \\
\hline Number paternal plants: & Species & 64 \\
Hybrids & 50 \\
\hline Total & 114 \\
\hline
\end{tabular}


Appendix 2. Summary of controlled crosses between 1973-1978.

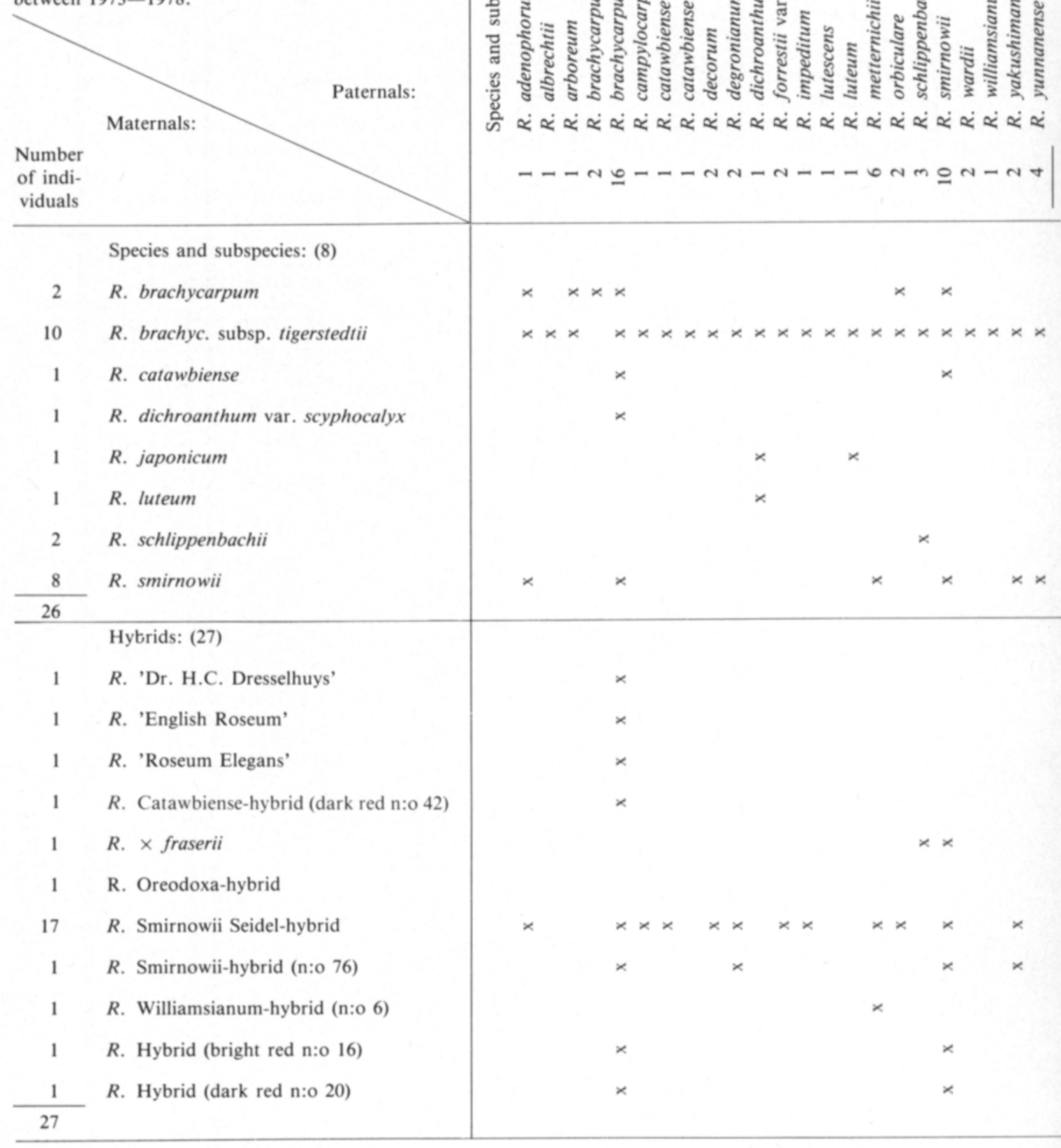

Total 53 individuals 


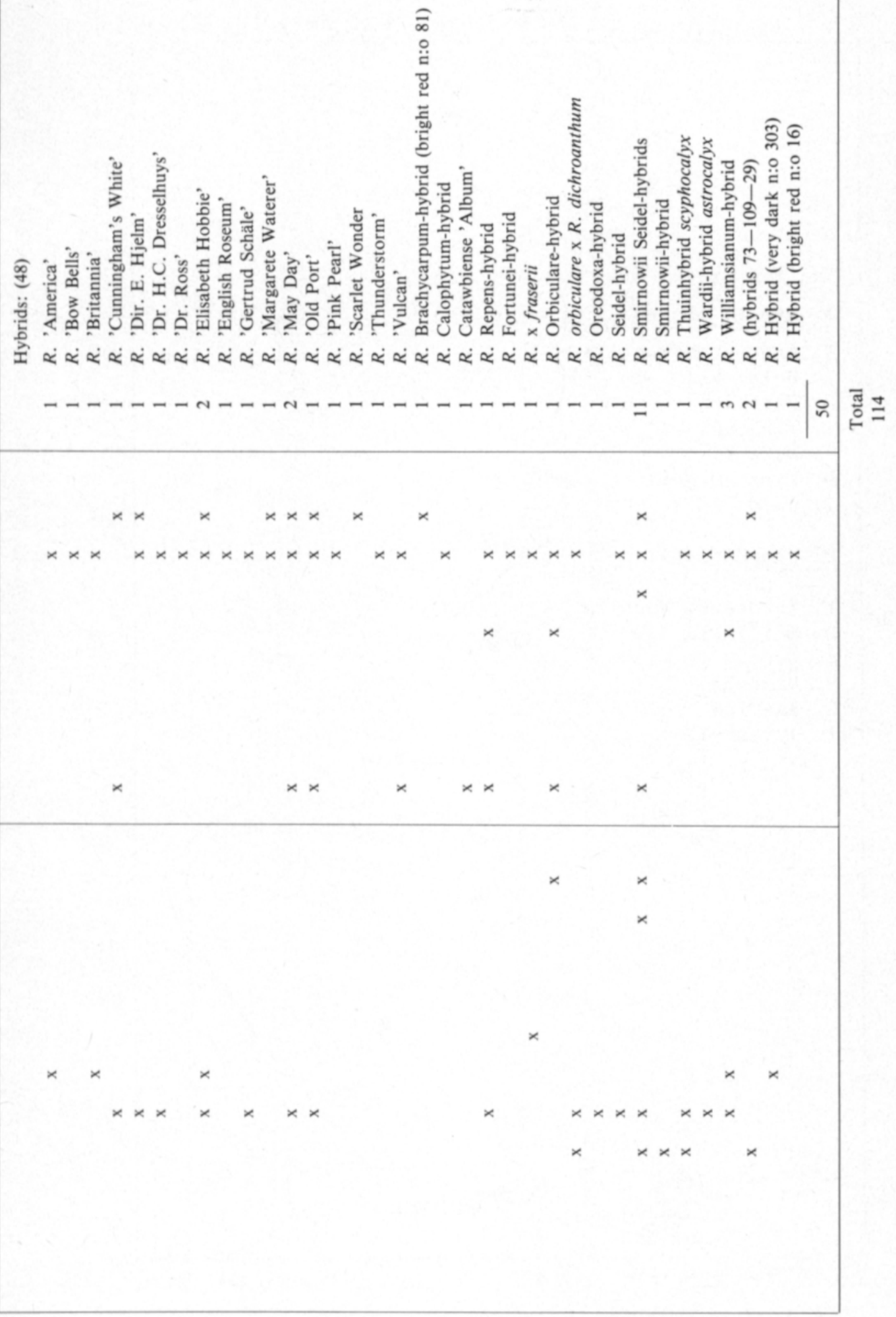




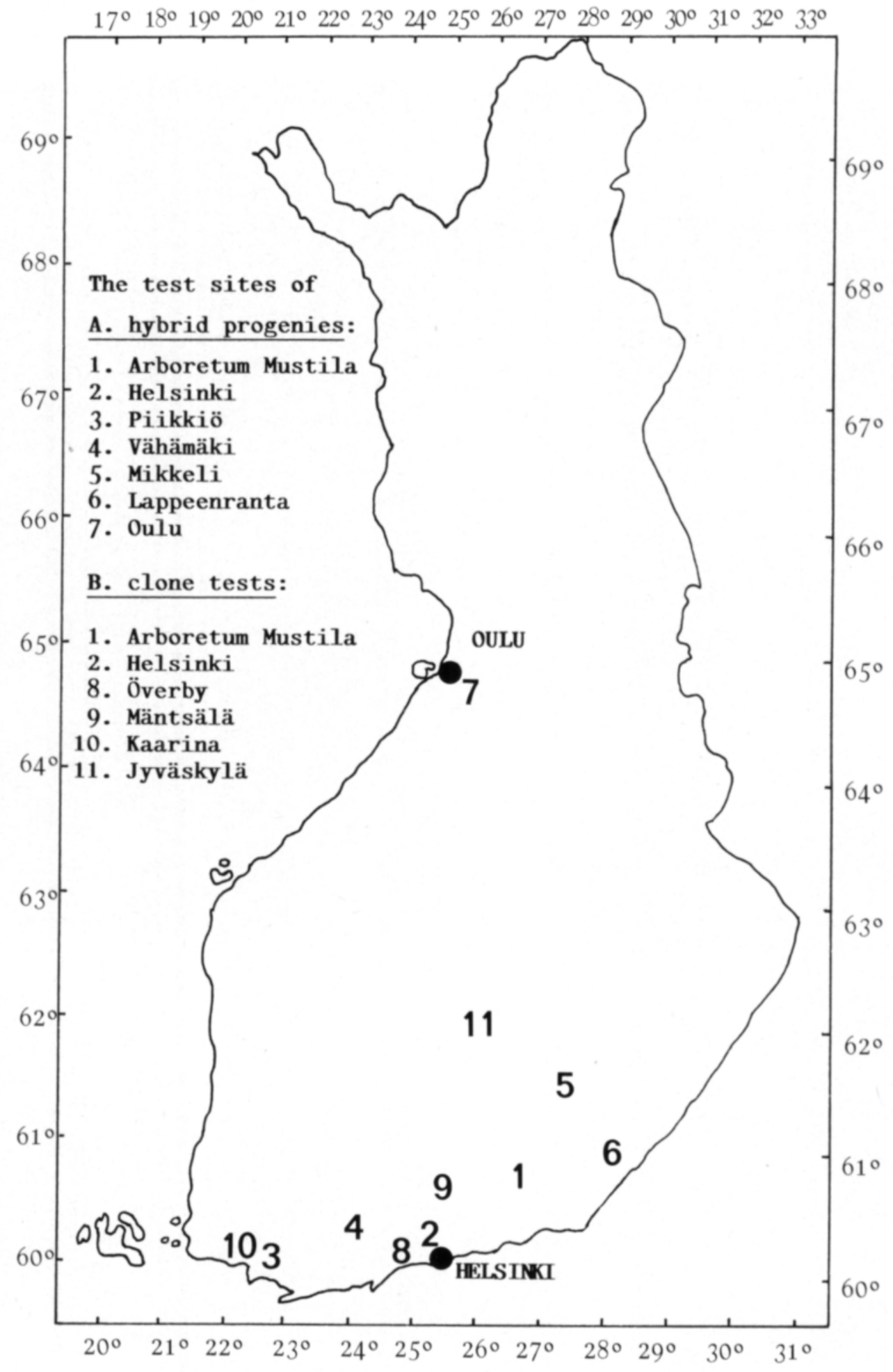

